\title{
ANALISIS KESUKSESAN IMPLEMENTASI APLIKASI ONLINE SINGLE SUBMISSION MENGGUNAKAN METODE DELONE DAN MCLEAN
}

\author{
I Made Windu Segara Kurniawan ${ }^{1}$, Gede Rasben Dantes², Gede Indrawan ${ }^{3}$ \\ ${ }^{1,2,3}$ Program Studi IImu Komputer, Universitas Pendidikan Ganesha \\ Singaraja, Indonesia
}

e-mail: mdwindu@gmail.com¹, rasben.dantes@undiksha.ac.id², gindrawan@undiksha.ac.id ${ }^{3}$

\begin{abstract}
Abstrak
Penelitian ini dilakukan atas dasar untuk mengetahui keberhasilan dari sebuah sistem informasi yang diterapkan dalam sebuah organisasi sehingga penelitian ini bertujuan untuk menganalisis kesuksesan implementasi aplikasi Online Single Submission (OSS) menggunakan metode Delone dan Mclean pada Dinas Penanaman Modal dan Pelayanan Terpadu Satu Pintu (DPMPTSP). Penelitian ini termasuk penelitian kuantitatif dengan metode survei. Populasi penelitian ini adalah pengguna sistem informasi yang berjumlah 55 orang. Sebanyak 48 responden dipilih sebagai sampel yang ditentukan dengan teknik group random sampling. Hasil Penelitian menunjukkan bahwa system quality, informasi quality, service quality dan individual impact memiliki pengaruh terhadap organizational impact sebesar $95,9 \%$ dan berpengaruh terhadap tingkat kepuasan pengguna sebesar $64,55 \%$ berada pada kategori cukup tinggi. Berdasarkan hasil tersebut, dapat disimpulkan terdapat kesuksesan implementasi aplikasi OSS menggunakan metode Delone dan Mclean pada DPMPTSP Kabupaten Buleleng. Dari hasil ini diharapkan kedepannya aplikasi OSS dapat di implementasikan pada lembagalembaga pemerintahan yang lain di Kabupaten Buleleng.
\end{abstract}

Kata kunci: analisis kesuksesan, online single submission, sistem informasi

\begin{abstract}
This research aims to analyze the successful implementation of the Online Single Submission (OSS) application using the Delone and Mclean method at the Investment Service and One Stop Integrated Service (DPMPTSP). This research is a quantitative research using a survey method. The population of this research is the users of the information system, amounting to 55 people. A total of 48 respondents were selected as a sample determined by the group random sampling technique. The results showed that system quality, information quality, service quality and individual impact had an influence on organizational impact of $95.9 \%$ and an effect on the level of user satisfaction by $64.55 \%$ which was in the high enough category. Based on these results, there is a successful implementation of the OSS application using the Delone and Mclean method at DPMPTSP Buleleng Regency. From these results, it is hoped that in the future the OSS application can be implemented in other government agencies in Buleleng Regency.
\end{abstract}

Keywords : analysis of success, online single submission, information system

\section{PENDAHULUAN}

Pemerintah

memperbaiki iklim penanaman modal di daerah dengan merumuskan salah satu kebijakan terkait dengan kepentingan tersebut, yaitu penerapan system Pelayanan Terpadu Satu Pintu (PTSP) yang didasarkan pada UU No. 25/2007 tentang Penanaman Modal. Untuk mewujudkan sistem pelayanan administrasi penanaman modal, PTSP memiliki strategi yang perlu dikembangkan melalui pembentukan Unit Pelayanan (UP) yang memiliki kewenangan khusus dalam 
pemberian perizinan bidang penanaman modal publik.

Kebijakan sistem PTSP ini juga dijalankan oleh Pemerintah Kabupaten Buleleng untuk meningkatkan kinerja pelayanan publik. Pelayanan perijinan terpadu ini diharapkan mampu mengatasi berbagai macam permasalahan dalam penyelenggaraan pelayanan perijinan di Kabupaten Buleleng. Sistem informasi terpadu yang banyak digunakan di berbagai perusahaan, universitas, lembaga pendidikan, dan lembaga lainnya, baik swasta maupun negeri.

Salah satu dinas yang menggunakan sistem teknologi informasi adalah Dinas Penanaman Modal dan Pelayanan Terpadu Satu Pintu (DPMPTSP) Kabupaten Buleleng. Sistem teknologi informasi ini sudah terintegrasi dalam sistem lainnya yang ada di Dinas Penanaman Modal dan Pelayanan ini, dan sistem informasi tersebut dinamakan Online Single Submission (OSS). Salah satu tujuan OSS adalah untuk mempermudah perizinan berusaha terutama bagi pelaku ekonomi kreatif [1]. Penerapan OSS diharapkan menjadi salah satu daya tarik investasi, karena dalam OSS terjadi pemangkasan birokrasi, sehingga proses yang semula berbelit-belit menjadi lebih pendek. Untuk Kabupaten Buleleng pengembangan dan penyelenggaraan OSS diimplementasikan dengan dibentuknya DPMPTSP.

DPMPTSP Kabupaten Buleleng sebagai lembaga pemerintah yang menyelenggarakan pelayanan administrasi perizinan di Kabupaten Buleleng sangat menyadari akan kepentingan dan hak masyarakat untuk mendapatkan pelayanan perizinan yang sebaik-baiknya. Pelayanan perizinan yang baik yaitu pelayanan yang sesuai dengan kriteria pelayanan prima yang dicirikan dengan pelayanan yang cepat, transparan dan pasti.

Namun dalam perjalanannya, pergerakan iklim investasi dan penanaman modal tidak didukung dengan penyelenggaraan pelayanan perizinan di Kabupaten Buleleng yang dinilai masih menemui beberapa kendala. Permasalahan pertama, persediaan sumber daya manusia
(SDM) yang masih kurang secara kuantitas dimana pada DPMPTSP Kabupaten Buleleng yang tersedia ada 34 orang, sedangkan jumlah pemohon perijinan dari tahun ke tahun mengalami peningkatan. Permasalahan kedua, dengan jumlah SDM (kelompok fungsional) yang tersedia pada DPMPTSP Kabupaten Buleleng yang berada di Front Office (FO) dan Back Office (BO) hanya sebanyak 8 Orang.

Hal ini tentu bisa menimbulkan permasalahan bagi pemohon perijinan seperti yang diungkapkan oleh seorang Staf frontoffice Bagian Penanaman Modal Sub Bidang Bagian Promosi, Pendaftaran, Data dan Pengembangan DPMPTSP Kabupaten Buleleng yang mengatakan bahwa keterlambatan penyelesaian berkas perijinan bisa saja terjadi apabila terjadi penumpukan berkas pemohon perizinan yang belum diolah akibat kurangnya SDM pada DPMPTSP Kabupaten Buleleng, apalagi terdapat beberapa jenis perijinan yang memerlukan kunjungan lapangan. Permasalahan ketiga, berdasarkan hasil wawancara dengan Ketua Bidang Penanaman Modal DPMPTSP Kabupaten Buleleng yang sering menjadi kendala dalam penyelenggaraan pelayanan perizinan dan penanaman modal di DPMPTSP Kabupaten Buleleng adalah terkait dengan pengadaan sarana dan prasarana yang dinilai belum memadai. Kondisi-kondisi seperti inilah yang menyebabkan penyelenggaraan pelayanan di DPMPTSP Kabupaten Buleleng belum dapat berjalan secara prima.

Dengan permasalahan yang seperti itu, Menteri Koordinator Bidang Perekonomian Darmin Nasution bersama dengan para menteri dan kepala lembaga terkait meresmikan penerapan Sistem OSS. Layanan Perizinan Berusaha Terintegrasi Secara Elektronik (PBTSE), yang lebih mudah disebut dengan nama generik OSS ini hadir dalam rangka pelayanan perizinan berusaha yang berlaku di semua Kementerian, Lembaga, dan Pemerintah Daerah di seluruh Indonesia, yang selama ini dilakukan melalui Perizinan Terpadu Satu Pintu (PTSP). berpendapat bahwa PTSP merupakan salah satu kegiatan 
penyelenggaraan perizinan dan nonperizinan, dimana proses pengelolaannya mulai dari tahap permohonan sampai kepada tahap penerbitan dokumen izin dilakukan secara terpadu dalam satu tempat [2]. In PTSP service, the process of issuance of business license starts from the perpetrator of registration, completing the requirement file, verification of files by service staff, data input, and surveys [3]. Selain melalui PTSP, masyarakat dapat mengakses Sistem OSS secara daring di mana pun dan kapan pun.

Berdasarkan paparan di atas, dapat dilakukan evaluasi untuk meningkatkan kebermanfaatan dan kesuksesan implementasi sistem informasi yang sudah diterapkan. Mengingat pentingnya sistem informasi untuk organisasi, ada banyak model yang digunakan untuk mengukur keberhasilan dari sebuah sistem informasi, salah satunya yaitu teori DeLone dan McLean (1992) tentang cara mengevaluasi kesuksesan dari sistem informasi yang dapat memberikan dampak secara individu (individual impact) dalam organisasi serta dampak secara organisasi (organizational impact). Hal ini didukung oleh penelitian yang dilakukan [4], yang berjudul Analisis Pengaruh System Quality, Information Quality, Service Quality Terhadap NetBenefit Pada Sistem KRS-Online. Penelitian yang dilakukannya berusaha mengetahui sejauh mana tingkat kesuksesan KRS-online dengan meneliti hubungan antar variabel dengan pendekatan Model Kesuksesan Sistem Informasi DeLone dan McLean.

Hasil ini menemukan bahwa implementasi teori DeLone dan McLean (1992) tentang cara mengevaluasi kesuksesan dari sistem informasi memberikan dampak secara individu dan dampak secara organisasi. Menurut DeLone dan McLean, untuk mengevaluasi kesuksesan dari sistem informasi, terdiri dari 6 konstruk atau varibel pengukuran yakni, kualitas dari kualitas sistem (system quality), kualitas informasi (information quality), konsumsi terhadap output (use), kepuasan pengguna (user satisfaction), dampak secara individu (individual impact) dan dampak secara organisasi (organizational impact) [5].

Untuk mengukur keberhasilan dari sebuah sistem informasi, peneliti mengadopsi teori yang dibuat oleh DeLone dan McLean (1992), peneliti menggunakan model pengukuran kesuksesan sistem informasi yang dihasilkan oleh DeLone dan McLean (1992) ini karena variabel yang peneliti gunakan dalam penelitian sama dengan variabel yang digunakan oleh DeLone dan McLean dalam penelitiannya, alur penelitian yang akan digunakan untuk pengukuran kesuksesan sistem informasi juga sama. Model ini digunakan oleh DeLone dan McLean untuk mengevaluasi kesuksesan dari pengaruh sistem informasi, terdiri dari 6 konstruk atau varibel pengukuran yakni, kualitas dari sistem informasi (system quality), sistem informasi (information quality), konsumsi terhadap output (use), kepuasan pengguna (user satisfaction), dampak secara individu (individual impact) dan dampak secara organisasi (organizational impact). Sedangkan pada penelitian ini, peneliti mencoba menggunakan model pengukuran tersebut pada skala organisasional yang berskala kecil di salah satu Dinas Pemerintahan yang berada di Kabupaten Buleleng yaitu Dinas Penanaman Modal dan Pelayanan Terpadu Satu Pintu (DPMPTSP) Kabupaten Buleleng untuk mengukur sejauh mana kesuksesan dari Aplikasi Online Single Submission (OSS) yang sudah diterapkan.

Berdasarkan latar belakang tersebut peneliti sangat tertarik untuk melakukan penelitian yang berjudul "Analisis Kesuksesan Implementasi Aplikasi OSS menggunakan Metode Delone dan Mclean pada Dinas Penanaman Modal dan Pelayanan Terpadu Satu Pintu Kabupaten Buleleng".

Tujuan dari penelitian ini adalah untuk mengevaluasi aplikasi Online Single Submission (OSS) menggunakan model pengukuran kesuksesan sistem informasi yang dihasilkan oleh [5] dengan cara sebagai berikut; (1) Menganalisis pengaruh system quality terhadap individual impact; (2) Menganalisis pengaruh information 
quality terhadap individual impact; (3) Menganalisis pengaruh service qualityterhadap individual impact; (4) Menganalisis pengaruh system quality, information quality, dan service qualityterhadap individual impact; (5) Menganalisis pengaruh system quality terhadap organizational impact; (6) Menganalisis pengaruh information quality terhadap organizational impact; (7) Menganalisis pengaruh service qualityterhadap organizational impact; (8) Menganalisis pengaruh kualitas sistem (system quality), kualitas informasi (information quality), dan kualitas pelayanan (service quality) terhadap dampak secara organisasi (organizational impact); (9) Menganalisis pengaruh system quality, information quality, service quality, dan individual impactterhadap organizational impact; (10) Menganalisis tingkat kepuasan pengguna terhadap kualitas sistem (system quality), kualitas informasi (information quality), dan kualitas pelayanan (service quality).

\section{METODE}

\section{Rancangan Penelitian}

Penelitian ini termasuk penelitian kuantitatif dengan metode survei. Metode survei adalah metode yang digunakan untuk mendapatkan data dari tempat tertentu yang alamiah, tetapi memberikan perlakuan dalam pengumpulan data [6]. Penelitian survei adalah penelitian yang mengambil sampel dari satu populasi dan menggunakan kuesioner sebagai alat pengumpulan data yang pokok [7]. Dalam penelitian survei diperlukan jumlah populasi yang cukup besar jika penelitinya menginginkan hasil yang mencerminkan kondisi nyata di lapangan.

\section{Populasi dan Sampel}

Populasi adalah sejumlah individu dalam suatu tempat yang mempunyai kualitas dan karakteristik tertentu yang ditetapkan oleh peneliti untuk dipelajari dan ditarik kesimpulan dari hasil penelitian yang dilakukan.Dalam penelitian ini, yang dijadikan populasi adalah pengguna sistem informasi pada Dinas Penanaman Modal dan Pelayanan Terpadu Satu Pintu (DPMPTSP) Kabupaten Buleleng dengan menggunakan aplikasi Online Single Submission (OSS) yang berjumlah 55 orang.

Sampel adalah bagian dari populasi yang diambil melalui cara-cara tertentu yang juga memiliki karakteristik tertentu, jelas, dan lengkap yang dianggap bisa mewakili populasi [8]. Cara mendapatkan sampel disebut dengan teknik sampling, dimana teknik yang digunakan harus dapat dipertanggung-jawabkan. Untuk menjaga besarnya sampel minimal dapat diolah datanya, Krecjek dan Morgan menyarankan pengambilan sampel minimal dari suatu populasi [9]. Jumlah sampel minimal dalam penlitian ini adalah sebanyak 48 orang.

\section{Variabel dan Instrumen Penelitian}

Variabel penelitian adalah segala sesuatu yang berbentuk apa saja yang ditetapkan oleh peneliti untuk dipelajari sehingga diperoleh informasi tentang hal tersebut kemudian ditarik kesimpulannya [10]. Pada penelitian ini, peneliti menggunakan tiga variabel penelitian yakni, variabel bebas (independent variable), variabel terikat (dependent variable, dan variabel mediasi (mediating variable).

Variabel bebas (independent variable) dalam penelitian ini adalah kualitas sistem (system quality), kualitas informasi (information quality), dan kualitas pelayanan (service quality). Variabel mediasi (intervening variable) pada penelitian ini adalah dampak secara individu (individual impact). Sedangkan varibel terikat (dependent variable) yang digunakan pada penelitian ini adalah dampak secara organisasi (organizational impact).

Instrumen yang digunakan dalam penelitian ini adalah kualitas sistem (system quality), kualitas informasi (information quality), kualitas pelayanan (service quality). dampak secara individu (individual impact) dan dampak secara organisasi (organizational impact).

\section{Teknik Analisis Data}


Dalam penelitian ini, akan digunakan dua teknik analisis yaitu analisis statistik deskriptif dan analisis inferensial. Statistik deskriptif (descriptive statistics) adalah statistik yang menggambarkan fenomena atau karakteristik dari data. Dalam penelitian ini memberikan gambaran mengenai demografi responden (umur, jenis kelamin, tingkat pendidikan). Sedangkan untuk mendeskripsikan data pada masing-masing variabel akan dicari harga rerata $(X)$, standar deviasi (SD), Modus (M), dan Median (Me). Untuk mendapatkannya diperlukan tabel distribusi frekuensi bergolong dan histogram untuk setiap variabel. Penyajian data distribusi frekuensi bergolong ditentukan dengan menggunakan rumus Sturges.

Statistik inferensial yang digunakan dalam penelitian ini adalah Analisis Jalur (Path Analysis) yaitu suatu teknik untuk menganalisis hubungan sebab akibat yang terjadi pada regresi berganda jika variabel bebasnya mempengaruhi variabel baik secara langsung maupun tidak langsung [11]. Data yang telah dikumpulkan dianalisis dengan program SPSS 16.0 for Windows. Untuk bisa mengalisis data dengan analisis jalur, terlebih dahulu dilakukan uji asumsi.

Sebelum dilakukan analisis korelasi, regresi sederhana maupun ganda, peneliti terlebih dahulu akan melakukan uji persyaratan analisis yaitu uji normalitas sebaran data, uji linearitas dan keberartian arah regresi, uji multikolinieritas, uji heteroskedastisitas dan uji autokorelasi.

Sebelum menguji hipotesis dengan menggunakan analisis regresi ganda dan korelasi ganda, terlebih dahulu dilakukan tehnik analisis regresi sederhana untuk menentukan hubungan antara variabel bebas dengan variabel terikat. Untuk menguji hipotesis pertama, kedua, dan ketiga menggunakan tehnik analisis regresi sederhana. Data yang telah dikumpulkan dianalisis dengan program SPSS 16.0 for Windows.

Untuk menguji hipotesis keempat dan kedelapan yang digunakan adalah tehnik regresi ganda dan regresi parsial. Data yang telah dikumpulkan dianalisis dengan program SPSS 16.0 for Windows. Untuk menguji korelasi secara bersama-sama antara $X_{1}, X_{2}, X_{3}$, terhadap $Y_{1}$ dan $X_{1}, X_{2}$, $X_{3}$, terhadap $Y_{2}$ menggunakan rumus korelasi ganda. Data yang telah dikumpulkan dianalisis dengan program SPSS 16.0 for Windows.

Untuk melihat kategori kesuksesan implementasi aplikasi OSS menggunakan metode Delone dan Mclean pada Dinas Penanaman Modal dan Pelayanan Terpadu Satu Pintu Kabupaten Buleleng, maka digunakan kualifikasi nilai rata-rata sumbangan efektif kepuasan pengguna yang dilakukan dengan menggunakan pedoman konversi skala lima [12] seperti Tabel 1.

Tabel 1 Kategori Nilai

\begin{tabular}{cc}
\hline Rentang Nilai (\%) & Kategori \\
\hline $83,35<x \leq 100$ & Sangat Tinggi \\
$66,68<x \leq 83,35$ & Tinggi \\
$50,01<x \leq 66,68$ & Cukup Tinggi \\
$33,34<x \leq 50,01$ & Cukup Rendah \\
$16,67<x \leq 33,34$ & Rendah \\
$0<x \leq 16,67$ & Sangat Rendah \\
\hline
\end{tabular}

\section{HASIL DAN PEMBAHASAN}

Data dalam penelitian ini disajikan hasil penelitian yang mencakup deskripsi tentang karakteristik dari masing-masing variabel penelitian, uraian tentang hasil pengujian persyaratan analisis dan uji hipotesis. Hasil penelitian yang dimaksud adalah menyangkut deskripsi data tentang system quality $\left(\mathrm{X}_{1}\right)$, informasi quality $\left(\mathrm{X}_{2}\right)$, service quality $\left(\mathrm{X}_{3}\right)$, individual impact $\left(\mathrm{Y}_{1}\right)$,

dan organizational impact $\left(\mathrm{Y}_{2}\right)$ DPMPTSP Kabupaten Buleleng. 
Untuk mendapatkan gambaran mengenai karakteristik distribusi skor dari masing-masing variabel, berikut disajikan skor tertinggi, skor terendah, harga rerata, simpangan baku, varian, median, modus, histogram dan kategorisasi dari masingmasing variabel. Di bawah ini disajikan rangkuman statistik seperti pada Tabel 2 berikut.

Tabel 2 Rangkuman Statistik Dari Variabel System Quality, Informasi Quality, Service Quality, Individual Impact dan Organizational Impact

\begin{tabular}{lrrrrr}
\hline \multicolumn{1}{c}{ Variabel } & \multicolumn{1}{c}{$\mathbf{X}_{\mathbf{1}}$} & \multicolumn{1}{c}{$\mathbf{X}_{\mathbf{2}}$} & \multicolumn{1}{c}{$\mathbf{X}_{\mathbf{3}}$} & \multicolumn{1}{c}{$\mathbf{Y}_{\mathbf{4}}$} & \multicolumn{1}{c}{$\mathbf{Y}_{\mathbf{2}}$} \\
Statistik & \multicolumn{1}{c}{ J } & 48 & 48 & 48 & 48 \\
Jumlah Sampel & 63,71 & 55,50 & 37,21 & 66,79 & 40,10 \\
Rata-rata & 63 & 55 & 38 & 66.50 & 39,50 \\
Median & 76 & 51 & 28 & 61 & 37 \\
Modus & 10,09 & 7,10 & 7,82 & 6,07 & 5,92 \\
Standar Deviasi & 101,83 & 50,47 & 61,15 & 36,81 & 34,99 \\
Ragam & 30 & 27 & 25 & 21 & 20 \\
Rentangan & 49 & 43 & 25 & 56 & 30 \\
Skor Minimum & 79 & 70 & 50 & 77 & 50 \\
Skor Maksimum & 3058 & 2664 & 1786 & 3206 & 1925 \\
Jumlah & & & & &
\end{tabular}

Keterangan:

$$
\begin{array}{ll}
\mathrm{X}_{1} & =\text { System quality } \\
\mathrm{X}_{2} & =\text { Informasi quality } \\
\mathrm{X}_{3} & =\text { Service quality } \\
\mathrm{Y}_{1} & =\text { Individual impact } \\
\mathrm{Y}_{2} & =\text { Organizational impact }
\end{array}
$$

\section{Pengaruh system quality terhadap individual impact}

Berdasarkan analisis data yang telah dilakukan, Secara normatif ditemukan bahwa system quality berada pada kategori baik. Selain itu, hasil analisis juga menunjukkan bahwa terdapat korelasi yang signifikan antara system quality dengan individual impact DPMPTSP Kabupaten Buleleng melalui persamaan garis regresi $\hat{y}$ $=44,094+0,356 X_{1}$ dengan Freg $=24,895$ $(p<0,05)$. Sedangkan korelasi yang signifikan terjadi antara system quality dengan individual impact sebesar 0,593 dengan $p<0,05$ dan variabel system quality dapat menjelaskan individual impact DPMPTSP Kabupaten Buleleng sebesar $35,1 \%$. Temuan ini mengindikasikan bahwa system quality mempunyai peranan penting dalam meningkatkan individual impact DPMPTSP Kabupaten Buleleng.

Kualitas sistem adalah kualitas dari sebuah sistem yang dijadikan sebagai performa atau kemampuan secara menyeluruh dalam sebuah sistem informasi yang terdiri dari kombinasi hardware dan software. Kualitas sistem merupakan ciri karakteristik kualitas yang diinginkan dari sistem itu sendiri dan kualitas informasi yang diinginkan informasi karakteristik produk.

Dalam sebuah sistem informasi, kualitas sistem sangat penting sebagai penunjang dari suksesnya sebuah sistem informasi. Kualitas sistem dalam sistem informasi, sangat berpengaruh terhadap dampak secara individu dalam sebuah organisasi. Kualitas sistem itu sendiri dianggap dapat mempengaruhi kepuasan pengguna. Semakin pengguna sistem menganggap bahwa kualitas sistem informasi tersebut tinggi maka pengguna akan semakin puas terhadap sistem informasi tersebut. Berdasarkan pemaparan di atas, maka dapat disimpulkan bahwa system quality memberikan pengaruh yang 
signifikan terhadap individual impact DPMPTSP Kabupaten Buleleng.

\section{Pengaruh information terhadap individual impact}

quality

Berdasarkan analisis data yang telah dilakukan, secara normatif ditemukan bahwa informasi quality berada pada kategori baik. Selain itu, hasil analisis juga menunjukkan bahwa terdapat korelasi yang signifikan antara informasi quality dengan individual impact DPMPTSP Kabupaten Buleleng melalui persamaan garis regresi $\hat{y}$ $=35,275+0,568 \cdot X_{2}$ dengan Freg $=36,463$ $(p<0,05)$. Sedangkan korelasi yang signifikan terjadi antara informasi quality dengan individual impact sebesar 0,665 dengan $\mathrm{p}<0,05$ dan variabel informasi quality dapat menjelaskan DPMPTSP Kabupaten Buleleng sebesar 44,2\%. Temuan ini mengindikasikan bahwa informasi quality mempunyai peranan penting dalam meningkatkan individual impact DPMPTSP Kabupaten Buleleng.

Dalam mengukur suksesnya penerapan sebuah sistem informasi, perlu diketahui bahwa kualitas informasi adalah salah satu varibel pokok yang digunakan untuk mengukur kepuasan pengguna ahir, ini dikarenakan bahwa kualitas informasi mengacu pada karakteristik informasi dan keakuratan data yang dihasilkan oleh sistem informasi. Kualitas sistem pada sebuah sistem informasi sangat besar dampaknya untuk meningkatkan produktifitas, efisiensi waktu, biaya operasional, serta manfaatnya dalam sebuah organisasi. Kualitas informasi yang dihasilkan suatu sistem informasi dapat mempengaruhi kepuasan pengguna [13]. Jika kualitas informasi yang dihasilkan sistem informasi itu baik dan akurat maka akan memuaskan pengguna sistem tersebut. Jadi dapat disimpulkan bahwa, kualitas informasi berpengaruh terhadap dampak secara individu sebuah organisasi dalam menggunakan sistem informasi.

\section{Pengaruh service quality terhadap individual impact}

Berdasarkan analisis data yang telah dilakukan, secara normatif ditemukan bahwa service quality berada pada kategori baik. Selain itu, hasil analisis juga menunjukkan bahwa terdapat korelasi yang signifikan antara service quality dengan individual impact DPMPTSP Kabupaten Buleleng melalui persamaan garis regresi $\hat{y}$ $=46,205+0,553 \cdot X_{3}$ dengan Freg $=47,602$ $(p<0,05)$. Sedangkan korelasi yang signifikan terjadi antara service quality dengan individual impact sebesar 0,713 dengan $p<0,05$ dan variabel service quality dapat menjelaskan individual impact DPMPTSP Kabupaten Buleleng sebesar $50,9 \%$. Temuan ini mengindikasikan bahwa service quality mempunyai peranan penting dalam meningkatkan individual impact DPMPTSP Kabupaten Buleleng.

Service quality atau kualitas pelayanan adalah sebuah layanan yang ditawarkan kepada pengguna (user) dalam menggunakan teknologi sistem informasi. Kualitas pelayanan salah satu pokok pengukur suksesnya penerapan sistem informasi dalam sebuah organisasi. Apabila kualitas pelayanan dalam sebuah sistem informasi tidak sesuai dengan apa yang diharapkan user, akan berdampak pada kinerja, produktifitas, efisiensi waktu, dan kebermanfaatan dalam organisasi. Jadi kesimpulannya bahwa, kualitas pelayanan dalam menggunakan system informasi mempunyai efek langsung atau pengaruh langsung terhadap dampak secara individu (individual impact) dalam sebuah organisasi.

\section{Pengaruh system quality, information quality dan service quality terhadap individual impact}

Berdasarkan analisis yang telah dilakukan, ditemukan bahwa terdapat korelasi yang signifikan secara bersamasama antara system quality, informasi quality, service quality terhadap individual impact melalui persamaan garis regresi $\hat{y}=$ $31,372+0,164 \cdot X_{1}+0,241 \cdot X_{2}+0,311 \cdot X_{3}$ dengan Freg $=25,561(p<0,05)$. Ini berarti terdapat hubungan secara bersama-sama antara system quality, informasi quality dan service quality terhadap individual impact DPMPTSP Kabupaten Buleleng. Hal ini mengindikasikan bahwa makin baik system quality, informasi quality dan service quality, 
semakin baik pula individual impact tersebut.

Temuan ini sejalan dengan penelitian yang dilakukan oleh Ashariyah [14] yang berjudul "Analisis Kualitas Pelayanan Di Badan Penanaman Modal dan Perizinan Terpadu Kabupaten Kulon Progo". Hasil penelitian menunjukkan bahwa kualitas pelayanan di Badan Penanaman Modal dan Perizinan Terpadu Kabupaten Kulon Progo termasuk dalam kategori memuaskan dengan persentase sebesar $65 \%$.

Dampak secara individu (individual impact) merupakan efek dari informasi terhadap perilaku pemakai yang terdiri dari kinerja pengguna, efisiensi waktu bagi pengguna, produktifitas dalam organisasi, biaya operasional, dan kebermanfaatan dalam menggunakan sistem informasi bagi pengguna. Dampak secara individu akan dipengaruhi secara menyeluruh oleh kulitas sistem, kualitas informasi, dan kualitas pelayanan dalam sistem informasi. Apabila kualitas pelayanan, kualitas sistem, dan kualitas informasi secara keseluruhan memiliki kualitas yang buruk atau tidak sesuai dengan apa yang dinginkan oleh pengguna (user) dalam menggukan sistem informasi, maka akan berdampak secara individu dalam organisasi, seperti; kinerja menurun, produktifitas menurun, banyak waktu yang terbuang, serta terjadinya peningkatan biaya operasional yang digunakan. Apabila sebaliknya kualitas pelayanan, kualitas sistem, dan kualitas informasi yang didapatkan sesuai dengan apa yang diingin user, maka kinerja, produktifitas, efisiensi waktu, serta biaya operasional akan meningkat.

\section{Pengaruh system quality terhadap organizational impact}

Berdasarkan analisis data yang telah dilakukan, Secara normatif ditemukan bahwa system quality berada pada kategori baik. Selain itu, hasil analisis juga menunjukkan bahwa terdapat korelasi yang signifikan antara system quality dengan organizational impact DPMPTSP Kabupaten Buleleng melalui persamaan garis regresi $\hat{y}=17,016+0,362 X_{1}$ dengan Freg $=28,462 \quad(p<0,05)$. Sedangkan korelasi yang signifikan terjadi antara system quality dengan organizational impact sebesar 0,618 dengan $p<0,05$ dan variabel system quality dapat menjelaskan organizational impact DPMPTSP Kabupaten Buleleng sebesar 38,2\%. Temuan ini mengindikasikan bahwa system quality mempunyai peranan penting dalam meningkatkan organizational impact DPMPTSP Kabupaten Buleleng.

Selain dampak secara individu, dampak secara organisasi dapat dipengaruhi oleh kualitas sistem. Dampak secara organisasi berikaitan dengan urusan internal dalam sebuah organisasi. Urusan ekternal dalam organisasi ini meliputi; keunggulan secara kompetitif, adanya kerja sama dengan pihak organisasi lainnya, dan dapat menciptakan urusan atau tugas yang berkaitan pada bidang akademik. Jadi, apabila kualitas sistem atau performa dari sistem informasi yang dimiliki tidak sesuai dengan apa yang diinginkan, maka akan terjadi kendala untuk urusan kerja sama dengan pihak organisasi lain. Apabila sebaliknya, kualitas sistem yang dihasilkan oleh sistem informasi ternyata baik atau sesuai dengan apa yang diinginkan oleh user, maka urusan kerja sama antar organisasi lainnya akan terjaga dengan baik.

\section{Pengaruh information quality terhadap organizational impact}

Berdasarkan analisis data yang telah dilakukan, secara normatif ditemukan bahwa informasi quality berada pada kategori baik. Selain itu, hasil analisis juga menunjukkan bahwa terdapat korelasi yang signifikan antara informasi quality dengan organizational impact DPMPTSP Kabupaten Buleleng melalui persamaan garis regresi $\hat{y}=8,856+0,563 . X_{2}$ dengan Freg $=38,752 \quad(p<0,05)$. Sedangkan korelasi yang signifikan terjadi antara informasi quality dengan organizational impact sebesar 0,676 dengan $\mathrm{p}<0,05$ dan variabel informasi quality dapat menjelaskan DPMPTSP Kabupaten Buleleng sebesar 45,7\%. Temuan ini mengindikasikan bahwa informasi quality mempunyai peranan penting dalam meningkatkan organizational impact DPMPTSP Kabupaten Buleleng. 
Penggunaan sistem informasi memiliki dampak secara organisasi dalam organiasi. Selain kualitas sistem yang memberikan efek atau pengaruh terhadap dampak secara organisasi bagi pengguna sistem informasi dalam sebuah organisasi, kualitas informasi juga memberikan dampak secara organisasi yang meliputi urusan eksternal organisasi. Apabila informasi pada sebuah sistem informasi yang didapatkan tidak akurat, maka urusan kerja sama antara organisasi lain jadi terganggu, sehingga tidak adanya keuntungan secara kompetitif terhadap organisasi lain. Apabila sebaliknya, kualitas informasi yang didapatkan kulitasnya baik atau sesuai dengan kebutuhan pengguna, maka urusan atau kerjasa sama dengan organisasi lain akan terjadi dan saling menguntung satu dengan yang lainnya.

\section{Pengaruh service quality terhadap organizational impact}

Berdasarkan analisis data yang telah dilakukan, secara normatif ditemukan bahwa service quality berada pada kategori baik. Selain itu, hasil analisis juga menunjukkan bahwa terdapat korelasi yang signifikan antara service quality dengan organizational impact DPMPTSP

Kabupaten Buleleng melalui persamaan garis regresi $\hat{y}=20,050+0,539 \cdot X 3$ dengan Freg $=47,432 \quad(p<0,05)$. Sedangkan korelasi yang signifikan terjadi antara service quality dengan organizational impact sebesar 0,713 dengan $p<0,05$ dan variabel service quality dapat menjelaskan organizational impact DPMPTSP Kabupaten Buleleng sebesar 50,8\%. Temuan ini mengindikasikan bahwa service quality mempunyai peranan penting dalam meningkatkan organizational impact DPMPTSP Kabupaten Buleleng.

Selain kualitas sistem dan kualitas informasi, kualitas pelayanan juga akan memiliki efek atau pengaruh terhadap dampak secara organisasi dalam penggunaan sistem informasi. Karena apabila kualitas pelayanan dalam menggunakan sistem informasi memuaskan, maka pengguna (user) sistem informasi akan terus menggunakan sistem tersebut sebagai fasilitas untuk memenuhi kebutuhan dalam organisasi. Sehingga, dengan didapatkannya kualitas pelayanan yang baik, maka hubungan kerjasama antar organisasi lain akan tetap terjaga, serta mendapat keuntungan secara kompetitif di dalam organisasi.

\section{Pengaruh system quality, information quality dan service quality terhadap organizational impact}

Berdasarkan analisis yang telah dilakukan, ditemukan bahwa terdapat korelasi yang signifikan secara bersamasama antara system quality, informasi quality dan service quality terhadap organizational impact melalui persamaan garis regresi $\hat{y}=31,372+0,164 . X_{1}+$ $0,241 \cdot X_{2}+0,311 \cdot X_{3}$ dengan Freg $=25,561$ $(p<0,05)$. Ini berarti terdapat hubungan secara bersama-sama antara system quality, informasi quality dan service quality terhadap organizational impact DPMPTSP Kabupaten Buleleng. Hal ini mengindikasikan bahwa makin baik system quality, informasi quality dan service quality, makin baik pula organizational impact tersebut.

Hasil penelitian ini sejalan dengan penelitian yang dilakukan oleh Hidayah [15]. Sejak diterapkannya aplikasi Sistem Informasi Tanda Tangan Elektronik (SITTEK), dapat mengatasi permasalahan yang terjadi dalam pengurusan proses perizinan DPMPTSP Kabupaten Sidoarjo.

Organizational impact (dampak secara organisasi) merupakan pengaruh dari informasi terhadap kinerja organisasi. Dampak organisasional ini terlihat dari distribusi informasi yang lebih cepat. Jika sistem informasi yang diterapkan baik dari segi kualitas sistem maupun kualitas informasi yang dihasilkan maka dapat menurunkan biaya distribusi informasi melalui penyederhanaan struktur organisasi. Distribusi informasi yang lebih baik dapat mempermudah dalam proses pengambilan keputusan yang cepat dan tepat. Dengan hal tersebut maka, dapat mempengaruhi kualitas sistem (system quality), kualitas informasi (information quality), dan kualitas pelayanan (service quality) dalam sebuh organisasi. 
9. Pengaruh system quality, information quality, service quality dan individual impact terhadap organizational impact

Terdapat pengaruh yang signifikan antara system quality, informasi quality, service quality, individual impact terhadap organizational impact DPMPTSP Kabupaten Buleleng. Pengujian perhitungan regresi ganda diperoleh persamaan garis regresi $\hat{y}=23,384+$ $0,033 \cdot X_{1}+0,031 \cdot X_{2}+0,009 \cdot X_{3}+0,889 \cdot Y_{1}$ dengan Freg $=252,747(p<0,05)$. Signifikan dengan pengaruh ( $R$ square $x 100$ ) sebesar $95,9 \%$.

Hasil Penelitian ini sejalan dengan hasil penelitian yang dikemukakan oleh Marselia [16]. Bahwa terdapat pengaruh system quality, information quality, service quality dan individual impact terhadap organizational impact.

Kualitas sistem, kualitas informasi, kualitas pelayanan, dan dampak secara individu dapat mempengaruhi dampak secara organisasi yang berkaitan dengan urusan dalam organisasi. Apabila kualitas sistem, kualitas informasi, kualitas pelayanan, dan dampak secara individu yang dihasilkan buruk atau tidak sesuai dengan apa yang diinginkan oleh pelanggan atau pengguna (user), maka akan berdampak buruk pada urusan organisasi dalam menggunakan sistem informasi. Apabila sebaliknya, kualitas sistem, kualitas informasi, kualitas pelayanan, dan dampak secara individu yang dihasilkan baik atau sesuai dengan apa yang diinginkan oleh pelanggan atau pengguna (user), maka akan berdampak baik pula pada urusan organisasi dalam menggunakan sistem informasi. Jadi dapat disimpulkan bahwa, kualitas sistem, kualitas informasi, kualitas pelayanan, dan dampak secara individu bersama-sama atau keseluruhan dapat mempengaruhi dampak secara organisasi atau urusan organisasi dalam menggunakan sistem informasi.

\section{Tingkat kepuasan pengguna terhadap system quality, information quality dan service quality}

Tingkat kepuasan pengguna dapat dilihat dari masing-masing sumbangan efektif (SE) variabel bebas system quality $\left(\mathrm{X}_{1}\right)$, informasi quality $\left(\mathrm{X}_{2}\right)$ dan service quality $\left(\mathrm{X}_{3}\right)$ terhadap varibel terikat yaitu individual impact $\left(\mathrm{Y}_{1}\right)$ dan organizational impact $\left(\mathrm{Y}_{2}\right)$. Berdasarkan hasil perhitungan yang diperoleh, kualitas sistem (system quality), kualitas informasi (information quality), dan kualitas pelayanan (service quality) berpengaruh terhadap tingkat kepuasan pengguna dengan tingkat kepuasan sebesar $64,55 \%$ berada pada kategori "cukup tinggi".

Hasil penelitian ini sejalan dengan penelitian yng dilakukan oleh Anggraini [17] yang berjudul "Analisis Pengaruh Pemanfaatan Sistem Informasi Pelayanan Perijinan (SIPPERI) Terhadap Dampak Kinerja Pegawai Pada Kantor Pelayanan Perijinan Terpadu (KPPT) Kota Palembang". Hasil dari penelitian dan analisis yang dilakukan dapat disimpulkan bahwa sistem inforamasi pelayanan perijinan memiliki pengaruh besar terhadap kinerja operasional karyawan KPPT Kota Palembang.

\section{SIMPULAN}

Berdasarkan hasil penelitian dan pembahasan yang telah dilakukan, maka dapat ditarik kesimpulan sebagai berikut.

1. Terdapat pengaruh yang signifikan antara system quality terhadap individual impact DPMPTSP Kabupaten Buleleng dengan koefisien korelasi sebesar 0,593, dengan pengaruh sebesar $35,1 \%$.

2. Terdapat pengaruh yang signifikan antara informasi quality terhadap individual impact DPMPTSP Kabupaten Buleleng dengan koefisien korelasi sebesar 0,665, dengan pengaruh sebesar $44,2 \%$.

3. Terdapat pengaruh yang signifikan antara service quality terhadap individual impact DPMPTSP Kabupaten Buleleng dengan koefisien korelasi sebesar 0,713, dengan pengaruh sebesar $50,9 \%$.

4. Terdapat pengaruh yang signifikan antara system quality, informasi quality, service quality, terhadap individual 
impact DPMPTSP Kabupaten Buleleng dengan pengaruh sebesar $63,5 \%$.

5. Terdapat pengaruh yang signifikan antara system quality terhadap organizational impact DPMPTSP Kabupaten Buleleng dengan koefisien korelasi sebesar 0,618, dengan pengaruh sebesar $38,2 \%$.

6. Terdapat pengaruh yang signifikan antara informasi quality terhadap organizational impact DPMPTSP Kabupaten Buleleng dengan koefisien korelasi sebesar 0,676, dengan pengaruh sebesar $45,7 \%$.

7. Terdapat pengaruh yang signifikan antara service quality terhadap organizational impact DPMPTSP Kabupaten Buleleng dengan koefisien korelasi sebesar 0,713, dengan pengaruh sebesar $50,8 \%$.

8. Terdapat pengaruh yang signifikan antara system quality, informasi quality, service quality, terhadap organizational impact DPMPTSP Kabupaten Buleleng dengan pengaruh sebesar $65,6 \%$.

9. Terdapat pengaruh yang signifikan antara system quality, informasi quality, service quality, individual impact terhadap organizational impact DPMPTSP Kabupaten Buleleng dengan pengaruh sebesar $95,9 \%$.

10. Kualitas sistem (system quality), kualitas informasi (information quality), dan kualitas pelayanan (service quality) berpengaruh terhadap tingkat kepuasan pengguna, dengan tingkat kepuasan sebesar $64,55 \%$ berada pada kategori "cukup tinggi".

Berdasarkan hasil dan kesimpulan dari penelitian ini, dapat diajukan beberapa saran sebagai berikut.

1. Penelitian berikutnya, disarankan agar menguji model kesuksesan sistem informasi yang dihasilkan oleh DeLone dan McLean (1992) pada skala industri yang skalanya lebih besar.

2. Bagi Dinas Penanaman Modal dan Pelayanan Terpadu Satu Pintu (DPMPTSP) Kabupaten Buleleng, agar mensosialisasikan penggunaan sistem OSS (Online single Submission) kepada masyarakat umum.
3. Dinas Penanaman Modal dan Pelayanan Terpadu Satu Pintu (DPMPTSP) Kabupaten Buleleng juga memberikan kontribusi kepada pengembang aplikasi agar teknologi (hardware dan software) pada sistem OSS (Online Single Submission) selalu diperbaharui.

\section{REFERENSI}

[1] P. P. Sari, "Pemanfaatan Teknologi Digital Sebagai Percepatan Berusaha Oleh Ekonomi Kreatif," J. Komunika J. Komunikasi, Media dan Inform., vol. 7, no. 3, 2018.

[2] U. B. Robby, "No Title," Inov. pelayanan perizinan melalui online single Submiss. Stud. Pada Izin Usaha Di Dinas Penanaman Modal Dan Pelayanan Terpadu Satu Pintu Kabupaten Bekasi, vol. 10, 2019.

[3] A. D. Saputra, "Public Service Transformation (A Case Study of Online Single Submission at The Office of Investment and Integrated Services Magelang Municipality)," J. IIm. IImu Adm. Publik J. Pemikir. dan Penelit. Adm. Publik, vol. 9, 2019.

[4] M. A. Fathoni, "Analisis Pengaruh System Quality, Information Quality, Service Quality Terhadap NetBenefit Pada Sistem KRS-Online," Kinetik, vol. 2, no. 3, pp. 197-206, 2017.

[5] W. H. DeLone and E. R. McLean, "Information Systems Success: The Quest For The Dependent Variable," Inf. Syst. Res., vol. 3, no. 1, pp. 6095, 1992.

[6] Sugiyono, Statistika Untuk Penelitian. Bandung: CV. Alfabeta, 2010.

[7] M. S. . Hasibuan, Manajemen Sumber Daya Manusia Perusahaan. Bandung: PT. Bumi Aksa, 2007.

[8] M. I. Hasan, Pokok - Pokok Materi Statistik 2, Cetakan Ke. Jakarta: PT Bumi Aksara, 2005.

[9] G. Dantes and Z. Hasibuan, "Priority of Key Success Factors (KSFS) on Enterprise Resource Planning (ERP) 
System Implementation Life Cycle," J. Enterp. Resour. Plan. Stud., no. November 2015, pp. 1-15, 2012.

[10] A. A. G. Agung, Metodologi Penelitian Kuantitatif (Perspektif Manajemen Pendidikan). Singaraja: Universitas Pendidikan Ganesha, 2018.

[11] Sunyoto, Riset Bisnis Dengan Analisis Jalur SPSS. Yogyakarta: Gava Media, 2001.

[12] Azwar, Metode Penelitian. Yogyakarta: Pustaka Pelajar, 2012.

[13] J. Livari, "An Empirical Test of the DeLone and McLean Model of Information System Success," Database Adv. Inf. Syst. Spring, 2005.

[14] N. Ashariyah, "Analisis Kualitas Pelayanan Di Badan Penanaman Modal Dan Perizinan Terpadu Kabupaten Kulon Progo," e J. Progr.
Stud. Pendidik. Adm. Perkantoran. UNY, p. 10, 2017.

[15] R. Hidayah, "Efektivitas Penerapan Layanan Sistem Informasi Tanda Tangan Elektronik (SITTEK) Di Dinas Penanaman Modal Dan Pelayanan Terpadu Satu Pintu (DPMPTSP) Kabupaten Sidoarjo," 2018.

[16] S. Marselia, "Analisis Kesuksesan Website E-Learning Management System (EMS) Dengan Menggunakan Model Delone dan McLean," JSIKA, vol. 7, no. 1, 2018.

[17] N. Anggraini, "Analisis Pengaruh Pemanfaatan Sistem Informasi Pelayanan Perijinan ( SIPPERI ) Terhadap Dampak Kinerja Pegawai Pada Kantor Pelayanan Perijinan Terpadu ( KPPT ) Kota Palembang," e J. Jur. Sist. Informasi. STMIK GI MDP, p. 10, 2017. 